\title{
Quality of Urban Tourism Area Services Based on Corporate Social Responsibility (CSR) for Travelers with Special Needs of Indonesia
} (Study in the CSR Tourism Area of the Colorful Villages of Jodipan Malang City)

\author{
Gede Pradiva Adiningrat ${ }^{1}$, Grahita Chandrarin ${ }^{2}$ and Sunardi $^{3}$ \\ ${ }^{1}$ University of Merdeka Malang and Bali State Polytechnic, Indonesia \\ ${ }^{2,3}$ University of Merdeka Malang, Indonesia
}

\begin{abstract}
The aim of the research is to identify the service quality in urban tourism with Corporate Social Responsibility for tourist with specific needs. Research was done in Malang City using descriptive qualitative research approach. Focus of the research includes SERVQUAL dimension, supporting factors and limitation factors and description of strategy to increase service quality. Data collection as done through observation, interviews, and document reviews. Result of the research shows that service quality for tourist with disability has been in good quality, by preparing for guidance and socialization related to sapta pesona, strengthening the area by forming tourism conscious groups, public awareness to maintain cleanliness, and be polite in the face of tourists. But there are still basic improvement. It can be reached through the preparation of human resources with competency, socialization to enhance the city tour destination, works professionalism and hospitality to the disable tourist. There are, however, limitation in facilities and accebility for tourist with specific needs, limited of data collection of tourist with specific needs, and some limitation faced by tourist with specific needs when they joint tourist program.
\end{abstract}

Keywords: SERVQUAL, Tourist, Urban Tourism, Corporate Social Responsibility, Spesific Needs, Standaritation, Tourism.

\section{INTRODUCTION}

Corporate social responsibilityan effort for companies to be able to balance and harmonize needs or targets for the economy. The existence of companies that implement corporate social responsibility processes within the community can provide a positive aspect of providing goods or providing services needed by the community (Suryandari) [1]. One application of corporate social responsibility is in the tourism sector.

Tourism is an important aspect in a country's economic development. The availability of facilities and services for tourists is an important factor like a tourism area. This factor is contained in the Law of the Republic of Indonesia Number 10 Year 2009 concerning Tourism which explains tourism as a tourism activity supported by various facilities and services provided by the local community, business people, government and regional governments.

Malang City is one of the 3 cities in the Greater Malang area between Malang Regency and Batu City. Seeing that Malang City does not have natural resources, other potentials of several potential tourism objects are developed and frequented by tourists. The availability of tourist areas offered by the City Government of Malang will increase the level of tourist visits to Malang City. Increasing the level of tourist visits to the city of Malang will open one of the opportunities for stakeholders in the field of tourism to develop tourism products, one of which is the development of a city tourism area based on corporate social responsibility (CSR) Tourism Coloring Village of Jodipan.

The colorful village of Jodipan is located on J1 Juanda Kelod Jodipan Malang. This village is located on the banks of the Brantas River and at first looked shabby if seen by the general public. In 2016, a creative idea that emerged from a group of students from the University of Muhammadhiyah Malang (UMM) who joined the Guys Pro changed the image of an area that was originally a slum into a colorful area (http://inovasi.lan.go.id). For the success of the development of this tourist area, this area managed to get a title in the 2016 Indonesia Attractiveness Award as a potential city for the tourism category, one of which is the Colorful Village Jodipan originating from CSR funds (http://malang.merdeka.com).

But in reality the implementation of the quality of service in the city tourism area still leads to services to tourists in general not to the specifics. In addition, the classic problem of the colorful tourist area of Jodipan is special training of human resources in the area which is currently still in the stage of awareness of citizens for cleanliness, and also the human resources of the city tourism area management through tourism awareness groups (Pokdarwis). The implementation of this special training is very 
important for providers of service quality to understand the perception of motivations of these special tourists in order to maximize positive experiences during a vacation (Carol) [2]. On the other hand there is no data collection for tourists with special needs in this region making these tourists served equally with other general tourists. Services for tourists with special needs in Malang should pay serious attention especially since Malang already has local regulations governing disability. If the corporate social responibility area is well implemented, it will be an opportunity to satisfy consumers so that they are loyal to the region (Pancayoga) [3].

\section{THEORETICAL BASIS}

\subsection{Service quality}

According to Wyckof in Pancayoga service quality is the expected level of excellence and control over customer needs [3]. As one of the tools in gaining competitive advantage, service quality is the difference between customer expectations and their perceptions of services that have been provided (Parasuraman in Arikan) [4]. Quality services will be able to meet the needs and expectations of users of these services (Hardiyahsyah) [5].

\subsection{City Tourism}

City Tourism is a tourism area product in which there are several concentrations of various forms such as attractions, amenities and accessibility that can attract tourists both from domestic and foreign countries and also includes tourists, business people and conferences (Priono) [6]. According to Cianga (2013: 34) the development of city tourism began in the 80s, beginning with the high need for tourism [7].

\subsection{Corporate Social Responsibility}

Purnomo defines corporate social responsibility as an obligation of companies to marry and in ways that are in accordance with company interests and the interests of the community [8]. On the other hand, the forms of social responsibility created by companies are not only for those interests, but also for the interests of stakeholders who are related to the company (Fortunately in Suryandari) [1]. These matters are important instruments to support the company's strategy, build the company's image and increase long-term profits (Kotler in Hartini) [9].

\subsection{Travelers with Special Needs}

Someone who has limitations will have an impact on differences in behavior with a decrease in the ability of him to perform activities and damage to vital organs of the brain that can make him have mental disorders, hyperactivity and blindness (Turgut) [10]. The National Commission on Human Rights (HAM) in the Center for the Study of Disability Services (PSLD) explains that people with disabilities are people who have physical, mental, sensory or intellectual limitations that are owned for a long period of time in their interactions in the midst of the environment and the attitudes of the people who subsequently encounter obstacles that make it difficult to participate fully and effectively based on equal rights of others [11].

\section{RESEARCH METHODS}

\subsection{Research design}

According to Moleong qualitative research will direct researchers to the focus of experience experienced by informants studied by researchers by determining the limits determined by a focus [12]. This type of research used in this study is descriptive. According to Santoso descriptive research is the process of collecting data for the purpose of describing important things in a group of data such as the average, variation of data and so on [13].

\subsection{Research focus}

3.3.

\begin{tabular}{|l|l|l|l|}
\hline No & $\begin{array}{c}\text { Research } \\
\text { focus }\end{array}$ & \multicolumn{1}{|c|}{ Definition } & \multicolumn{1}{c|}{ Indicator } \\
\hline 1 & $\begin{array}{l}\text { Service } \\
\text { quality }\end{array}$ & $\begin{array}{l}\text { Is a differentiator between customer } \\
\text { expectations and their perceptions of } \\
\text { services that have been provided. } \\
\text { (Parasuraman in Arikan 2013: 306) }\end{array}$ & $\begin{array}{l}\text { According to Parasuraman in Arikan (2013: 306): } \\
\text { Responsiveness } \\
\text { Reliability (realiability) } \\
\text { Physical Proof (tangibles) } \\
\text { Guarantee } \\
\text { Empathy (empathy) }\end{array}$ \\
\hline 2 & $\begin{array}{l}\text { Supporting } \\
\text { factors and } \\
\text { inhibiting }\end{array}$ & $\begin{array}{l}\text { Factors that support and hinder the } \\
\text { implementation of CSR tourism } \\
\text { service quality for tourists with }\end{array}$ & $\begin{array}{l}\text { Supporting factors: } \\
\text { Support related to special services in tourist areas, the existence of } \\
\text { special regional regulations for persons with disabilities and the }\end{array}$ \\
\hline
\end{tabular}


International Journal of Advances in Scientific Research and Engineering (ijasre), Vol 6 (8), August -2020

\begin{tabular}{|c|c|c|c|}
\hline No & $\begin{array}{l}\text { Research } \\
\text { focus }\end{array}$ & Definition & Indicator \\
\hline & factors & special needs & $\begin{array}{l}\text { awareness of residents with tourist areas } \\
\text { Obstacle factor: } \\
\text { The absence of specific HR training, facilities and accessibility that } \\
\text { are not yet friendly and the absence of data collection of tourists } \\
\text { with special needs on holiday to the colorful village of Jodipan }\end{array}$ \\
\hline 3 & $\begin{array}{l}\text { Service } \\
\text { strategy }\end{array}$ & $\begin{array}{l}\text { Service strategy is an effort in } \\
\text { planning fulfillment of customer } \\
\text { satisfaction }\end{array}$ & $\begin{array}{l}\text { socialization of enchanting sapta, innovation of city tourism areas, } \\
\text { development of tourism awareness groups, tourist emergency } \\
\text { training, capacity building of communities in tourist destinations, } \\
\text { and also specifically planning to complement special facilities and } \\
\text { also pay attention to special service models }\end{array}$ \\
\hline 1 & $\begin{array}{l}\text { Service } \\
\text { quality }\end{array}$ & $\begin{array}{l}\text { Is a differentiator between customer } \\
\text { expectations and their perceptions of } \\
\text { services that have been provided. } \\
\text { (Parasuraman in Arikan 2013: } 306 \text { ) }\end{array}$ & $\begin{array}{l}\text { According to Parasuraman in Arikan (2013: 306): } \\
\text { Responsiveness } \\
\text { Reliability (realiability) } \\
\text { Physical Proof (tangibles) } \\
\text { Guarantee } \\
\text { Empathy (empathy) }\end{array}$ \\
\hline 2 & $\begin{array}{l}\text { Supporting } \\
\text { factors and } \\
\text { inhibiting } \\
\text { factors }\end{array}$ & $\begin{array}{l}\text { Factors that support and hinder the } \\
\text { implementation of CSR tourism } \\
\text { service quality for tourists with } \\
\text { special needs }\end{array}$ & $\begin{array}{l}\text { Supporting factors: } \\
\text { Support related to special services in tourist areas, the existence of } \\
\text { special regional regulations for persons with disabilities and the } \\
\text { awareness of residents with tourist areas } \\
\text { Obstacle factor: } \\
\text { The absence of specific HR training, facilities and accessibility that } \\
\text { are not yet friendly and the absence of data collection of tourists } \\
\text { with special needs on holiday to the colorful village of Jodipan }\end{array}$ \\
\hline 3 & $\begin{array}{l}\text { Service } \\
\text { strategy }\end{array}$ & $\begin{array}{l}\text { Service strategy is an effort in } \\
\text { planning fulfillment of customer } \\
\text { satisfaction }\end{array}$ & $\begin{array}{l}\text { socialization of enchanting sapta, innovation of city tourism areas, } \\
\text { development of tourism awareness groups, tourist emergency } \\
\text { training, capacity building of communities in tourist destinations, } \\
\text { and also specifically planning to complement special facilities and } \\
\text { also pay attention to special service models }\end{array}$ \\
\hline
\end{tabular}

\subsection{Research Samples}

In selecting and determining objects in the study site, researchers choose randomly according to the data collection that they want to collect. In understanding phenomena in the study area, researchers do not generalize populations, but rather develop in-depth exploration of individuals or sites intentionally (purposefully). The type of approach determined by the researcher is by sampling the maximum variation (maximal variation sampling).

\subsection{Data Analysis Techniques}

Miles, Huberman and Saldana mention that there are three stages in analyzing data in qualitative methods, including the following [14]:

1) Data Condensation (Data condensation)

2) Display Data (Data Presentation)

3) Data Conclusion / Verifying (Conclusions and data verification). 


\section{DISCUSSION}

\subsection{Quality of Urban Tourism Area Services Based on Corporate Social Responsibility for Travelers with Special Needs.}

From the results of research conducted by researchers related to the quality of service in the city tourism area based on corporate social responsibility CSR produces that the quality of service is one of the factors that is one of the determinants in maintaining the area to be in accordance with the needs of tourists. This is stated in the vision and mission stated in Malang City's RPJMD to formulate the Vision and Mission of Malang City in 2013 to 2018, one of which is to improve the tourism sector by increasing the quality and equity of services. The City Government of Malang in this case realizes that the tourism potentials in Malang must be balanced with good services in order to facilitate the fulfillment of tourist needs by providing facilities and accessibility. So that service providers in the tourist area must be able to understand the behaviors of the tourists in order to know how to satisfy their needs (Khalief) [15].

The quality of service itself can be assessed from five aspects of indicators namely responsiveness, reliability, physical evidence, assurance and empathy

1) Responsiveness

Responsiveness or better known as responsiveness is one of the ability of service providers to respond immediately to the needs of customers or service recipients (Arikan) [4]. As an effort for the tourist area to achieve a good service, it requires responsive services and can also meet the needs of tourists both in general and those who have special limitations in carrying out their activities while in the Colorful Village Jodipan.

2) Reliability

Reliability refers to providing accurate and appropriate services to service users. One of the efforts made in the Colorful Village Kampong as an effort to create special services for tourists with special needs is to pay attention to the best service for tourists based on Sapta Enchantment. The results of an interview by the Head of the Destination Sexai Department of Culture and Tourism of Malang City Endang Sumarti which stated that with the establishment of a tourism awareness group, the community was moved rather than the official's efforts to build awareness of their tourism and efforts in making this decision as a task in carrying out actions in accordance with the goals of the values community (Wartick in Solihin) [16]

3) Physical Proof

The Jodipan Colorful Village area strives to fulfill special services in the form of providing special handles in several corners of the tourist area and also a sloping road that can be passed by wheelchair users. But from the results of research that shows that the road is not friendly due to steep and also realized by the Head of the Destination Section of the Culture and Tourism Office of Malang City Endang Sumarti who mentioned that the area was vulnerable and also gave advice to be accompanied and also some suggestions given by Head of Promotion Section of Malang City Culture and Tourism Office who suggested to be able to choose an alternative location besides this tourist village could be one of the solutions made so that tourists' expectations do not change when directly visiting the area.

4) Guarantee

The collateral in Jodipan Colorful Village is by applying good and correct management. This was conveyed by Chairman of RW 02 Jodipan Sony Parin and also Chairman of Pokdarwis Marzuki who together participated in coaching conducted by the Malang City Culture and Tourism Office related to the direction of the management of the tourist area, how to respond to tourists well and receive some input if there is something that is not corrected. one of the efforts made to form the accessibility of this interaction that can attract tourists to the region (Priono) [6].

5) Empathy

The Jodipan Colorful Village which establishes Sapta Pesona as part of forming a good communication between the manager of the tourist area and tourists. The direction obtained by the Chairperson of RW 02 Jodipan regarding the manner of courtesy and also the training and understanding of enchantment delivered by the Head of the Endang Sumarti Destination Section became one of the ways to form communication so that there would be an increase in service from everyone who felt directly from the service.

4.2. Supporting Factors and Inhibiting Factors in the Quality of Service for City Tourism Areas Based on Corporate Social Responsibility (CSR) for Travelers with Special Needs

a. Supporting factors

1) Support for Special Services in the Tourism Area

2) Special Regional Regulation for Persons with Disabilities

3) There is Public Awareness with the Tourist Area

b. Obstacle factor

1) Lack of Specific Human Resources Training

2) Facilities and accessibility that are not yet friendly to tourists are of particular limitations

3) There Is No Data Collection Of Travelers With Special Needs To Vacation In Jodipan Colorful Village 


\subsection{Strategies in Efforts to Improve the Quality of Urban Tourism Area Services Based on Corporate Social Responsibility (CSR) for Travelers with Special Needs.}

From the results of the research obtained in Colorful Village Jodipan it was found that the area has strategic steps as an effort in developing the tourist area. The initial steps taken by the Chairman of RW 02 Jodipan Sony Parin and also the Chairman of Pokdarwis Marzuki to promote awareness of the environment by not littering and forming public awareness of the village area.

As one of the thematic villages that is already well-known in the tourism industry, this area also strengthens the ability of human resources in understanding the needs of tourists and also makes a new menu model concept as an effort for service providers to understand the behavior and needs of guests so they know how to satisfy customers (Khalief) [15].

In addition, the strategies undertaken include increasing specific services to them by paying special attention to service models and also directing awareness-raising regarding emergencies to be one way to create quality services according to customer needs (Aurel) [17].

\section{CONCLUSIONS AND RECOMMENDATIONS}

\subsection{Conclusion}

a. The research results obtained by researchers in the field indicate the application of service quality in the Jodipan Multicolored Village which is practically going well. Efforts are made by the manager of the tourist area by increasing human resources with socialization and guidance sapta charm. Strengthening community assistance with the establishment of tourism awareness groups, the availability of special facilities in this tourist area such as sloping roads and the existence of a special handle, responding to tourists with special needs when experiencing difficulties, awareness of the local community to protect the surrounding environment and be polite in responding to tourists becoming one of the qualities displayed in this region. There is a comfortable tourist response, and also the acceptance of community responses to their existence is a benchmark in how far the service is delivered to these tourists. However, from the positive results, there are still some obstacles in trying to improve the quality of services such as this steep and dangerous tourist area, there are no specific service standards either from Pokdarwis or Disbudpar, there is no specific training in any socialization or guidance, funding issues in developing special services, coordination between agencies that is not easy because there are no specific sectors in some agencies and there is a barrier of tourists in the response around

b. The supporting factors of the quality of service in the city tourism area based on corporate social responsibility (CSR) for tourists with special needs in the Colorful Village Jodipan Malang City are the support related to special services in the tourist area, the existence of special regional regulations for persons with disabilities and public awareness with the tourist area. Then the inhibiting factors are the absence of special training in human resources, facilities and accessibility that are not yet friendly and the absence of data collection of tourists with special needs on holiday to the Jodipan Multicolored Village.

c. The Culture and Tourism Office of Malang City together with the Manager of the Jodipan Colorful Village of the Colorful Village set this tourist area to be worth visiting by promoting environmental awareness and implementing quality services. The results of research in the field, Department of Culture and Tourism of Malang City currently apply seven strategies in the Jodipan Colorful Warni Village area that can be linked to services for tourists with special needs in order to implement quality services and can be felt by all tourists visiting the area. These seven strategies include the socialization of the Sapta Charm, the innovation of the city tourism area, the development of a tourism awareness group, the emergency training of tourists, the development of community capacity in tourist destinations,

\subsection{Suggestion}

1) Academic Benefits

Suggestions for academics, especially for the development of special management in the field of corporate social responsibility, are to explore again how to apply special service quality related to the needs of tourists who have limitations. Exploring CSR knowledge more deeply related to service issues in a different perspective through some of the latest international journals and also theoretical books related to CSR management in special services because it relates to special markets in the social field that can add insight into management, especially CSR.

2) Practical benefits

The manager of the Colorful Village Jodipan tourism area is expected to be able to improve the best services for tourists with special needs. Through Regional Regulation (Perda) No. 02 of 2014, the tourist village area to improve the quality of services for tourists with special needs. In various cross-cutting sectors in the tourism environment, the Culture and Tourism Office of Malang City can also provide specific appeals to each SKPD of the relevant agencies and deal directly with the Colorful Village Jodipan area to collaborate together to form one of the specific rules regarding providing the best service. for special needs tourists.

In some of the future socialization and coaching, the Culture and Tourism Office of Malang City in particular can include special service points for tourists with special needs both ethically in the tourist area and further strategies that can be 
carried out for the manager of the tourism area in this case the Chairman of RW 02 Jodipan and Chairperson of the Tourism Awareness Group (Pokdarwis) so that they can apply the sapta of charm and create security and comfort for special tourists when traveling side by side with general tourists. Some things that have been stipulated in Regional Regulation (Perda) Number 02 of 2014, Law No. 8 of 2016 and also listed in the 2013 UNWTO relating to accessibility for special limitations in tourist areas can be an additional reference in subsequent studies across government agencies. Then optimizing the budget allocation is not only focused on the development of tourism awareness groups, but for special facilities. Collaboration between SKPD through the Culture and Tourism Office, Social Service and Tourism Area Managers will be able to be a positive thing for stakeholders related to meeting the needs of special tourists while in Colorful Village Jodipan Multicolored Colors so that they are met properly. Guiding and periodic socialization to human resources in the tourist village area, to the public, tourism awareness group and RW 02 Jodipan Chairman and also other stakeholders about the importance of understanding tourists with special needs. This can be done in tourism collaborative activities, special training and also during the awareness of tourism awareness.

Specifically, in the future the human resources in Colorful Village Jodipan should pay attention to ethics in serving disability. The manager of the tourism area can invite several disability volunteers or other relevant stakeholders who already understand the disability to help in the development of this special training. This special training such as how to serve special tourists is one thing that must be considered. In addition to collaborating with the government in this case the Malang City Culture and Tourism Office, the manager of the tourism area can also collaborate with the Malang City Social Service, Deaf Roots, Deaf Partners throughout the City of Malang and other stakeholders to add new knowledge related to special needs. In the future Disbudpar can collaborate with the Social Service to start doing regular data collection in Colorful Village Jodipan or in general in Malang related to the number of special tourists who are visiting this tourist area. If this is considered, this can be a good advantage not only for the government but also for all relevant stakeholders because by knowing how many tourists there are, the government and the manager of the tourism area can look for specific strategies to hook this market to the Jodipan Colorful Village or generally to the city of Malang. And for corporate social responsibility funders, in the future when giving CSR funds, they must pay attention to four elements of strategy, namely community development, assistance, organizing and empowering so that human resources in the region can be empowered to become quality resources. In the future also in providing CSR funds to tourist areas both in the tourist village or other destinations in the city tourist area, must pay attention to and consider factors related to accessibility, amenities and attractions.

\section{Note}

Gede Pradiva Adiningrat is Student in Master in Management Program, University of Merdeka Malang and Politeknik Negeri Bali, Indonesia.

Corresponding author: Sihwahjoeni

\section{REFERENCES}

1. Suryandari, Nikmah. 2012. CSR dan Citra Perusahaan. Madura. Prosiding Semnas Manajemen II

2. Carol, Lu. 2015. Service Quality and Customer Satisfaction. Taiwan. International Journal of Culture

3. Pancayoga, Robert. 2017. Pengaruh Kualitas Pelayanan dan Corporate Social Responsibility Terhadap Kepuasan Konsumen. Manado. Jurnal EMBA

4. Arikan. 2013. The Impact of Corporate Social Responsibility, Service Quality and Customer Company Identification on Customers. Istanbul. Int. Strategic Management Confrence

5. Hardiyansyah. 2011. Kualitas Pelayanan Publik. Yogyakarta. Penerbit Gava Media

6. Priono, Y. 2012. Identifikasi Produk Wisata Pariwisata Kota (Urban Turism).

7. Cianga-Nicolae dan Popescu C.Antoaneta.(2013).Green Spaces And Urban Tourism Developmentin CraiovaMunicipality In Romania. European Journal Of Geography. Vol. 4 No. 2 Tahun 2013. 34-45 .

8. Purnomo, Hadi. 2012. Corporate Social Responsibility Berbasis Green Marketing Dalam Upaya Pemberdayaan Usaha Kecil. Madura. Prosiding Semnas Manajemen II

9. Hartini, Sri. 2012. Revitalisasi Kebijakan Pemberdayaan Ekonomi Usaha Kecil Kreatif Berbasis Manajemen CSR. Malang. Prosiding Semnas Manajemen II.

10. Turgut, Var. 2011. A Study on the Travel Patterns of Physically disabled People. Turkey. Journal of Tourism Research

11. Pusat Studi Layanan Disabilitas Universitas Brawijaya. 2014. Indonesia Journal of Disability Studies. Malang. Penerbit PSLD

12. Moleong, J. 2006. Metode Penelitian Kualitatif(Edisi Revisi). Bandung: Penerbit PT Remaja Rosdakarya

13. Santoso, Singgih. 2015. Menguasai Statistik Non Parametrik. Jakarta. PT Elex Media Komputindo

14. Miles,Huberman, \& Saldana. 2014. Qualitative Data Analysis. United States of America. SAGE Publication 
International Journal of Advances in Scientific Research and Engineering (ijasre), Vol 6 (8), August -2020

15. Khalief, Nimer Abu. 2012. Service Quality Management in Hotel Industery. Penang. Canadian Center of Science and Education.

16. Solihin, Ismail. 2009. Corporate Social Responsibility “from charity to sustainability”. Jakarta. Salemba Empat

17. Aurel, Mihail. 2016. Measuring Service Quality in Tourism Industry. Romania. International Symposium in Management. 